\title{
PACKED BED UP-FLOW ANAEROBIC SLUDGE BLANKET COMBINED WITH MULTISTAGE SAND FINE ROUGHING FILTRATION FOR MUNICIPAL WASTEWATER TREATMENT AND REUSE
}

\author{
S.I. ABOU-ELELA ${ }^{1}$, M.E. FAWZY ${ }^{1} \&$ W. ABDEL-HALIM ${ }^{2}$ \\ ${ }^{1}$ Water Pollution Research Department, National Research Center, Cairo, Egypt. \\ ${ }^{2}$ Housing and Building National Research Center, Cairo, Egypt.
}

\begin{abstract}
There is a high potential for reuse of treated wastewater due to the shortage of renewable water resources for agricultural purposes in many countries of the world. To achieve this goal, an integrated anaerobic pilot plant treatment system treating almost $10 \mathrm{~m}^{3} /$ day of wastewater was designed, manufactured and installed in a nearby wastewater treatment plant. The treatment scheme consists of a packed bed up-flow anaerobic sludge blanket (P-UASB) with corrugated lamella sheets, followed by inclined plate settler (IPS). However, to obtain a treated effluent amenable for reuse, post-treatment was carried out using a multi-stage roughing fine filtration unit (MSRFF). The pilot plant was operated at average hydraulic flow rate of $10 \mathrm{~m}^{3} /$ day with average organic loading rate of $3.27 \mathrm{~kg}$ chemical oxygen demand (COD) $\mathrm{m}^{3} /$ day. Two retention times in P-UASB namely, 4 and $6 \mathrm{~h}$ were investigated. The performance of the treatment scheme was monitored via physico-chemical as well as bacteriological and parasitological analysis. Treatment of wastewater by P-UASB followed by IPS produced a high quality effluent. Average removal rates of COD, biochemical oxygen demand (BOD) and total suspended solids (TSS) were 75, 70.6 and 91.3, respectively, with average corresponding residual values of 75,58 and $18 \mathrm{mg} / \mathrm{l}$. However, to obtain sustainable quality of treated effluent for reuse, post-treatment using MSRFF improved the quality of treated wastewater both chemically and biologically. The average residual concentrations of COD, BOD and TSS were 60, 34 and $10.9 \mathrm{mg} / \mathrm{l}$, respectively, while almost complete removal of Fecal Coliforms was achieved. The treatment scheme proved to be a very promising approach for wastewater treatment for reuse in agricultural purposes.
\end{abstract}

Keywords: Anaerobic treatment, municipal wastewater, multi-stage sand roughing fine filtration, packed bed sludge blanket, reuse.

\section{INTRODUCTION}

The need for renewable water resources emerges from the reason of increasing water scarcity in many parts of the world. One of the approaches is the potential reuse of treated wastewater in agricultural purposes. To achieve this goal, wastewater should be treated to the level required for reuse depending on local regulation. In Egypt, water scarcity is one of the serious problems, nowadays. It is expected that in the next few decades, Egypt is going to experience water scarcity. Poor sanitation is part of these problems as 5-6 BCM/year of municipal wastewater are not utilized and $3 \mathrm{BCM}$ are used in agriculture without treatment, which causes environmental and hygienic problems [1]. Currently, 0.7 BCM of treated wastewater is being used in irrigation of which $0.26 \mathrm{BCM}$ is undergoing secondary treatment and $0.44 \mathrm{BCM}$ is undergoing primary treatment, mainly in direct reuse in desert areas or indirect reuse through mixing with agricultural drainage water. In general, treated wastewater use is of tremendous potential importance in Egypt [2].

The problem of sanitation in rural areas of Egypt (40 million) increases due to the increase in population density and the increase in water consumption as a result of supplying drinking water to villages. The sanitation level in the rural areas is not more than $12 \%$. The high construction, operation and maintenance costs for centralized conventional wastewater collection and treatment system represent an obstacle for the Egyptian Government in the installment of 
such a system in rural areas and small communities. Moreover, the skills needed for operation and continuous monitoring programs are absolutely unavailable on a village scale. Due to this, the onsite low cost options or decentralized sanitation systems are all becoming interesting solution for application and testing [3]. According to the World Bank, the greatest challenge in the water and sanitation sector over the next decades will be the implementation of low cost sewage treatment that will, at the same time, permit selective reuse of treated effluent for agricultural purposes [4].

One of the most promising techniques for onsite treatment is the use of packed bed up-flow anaerobic sludge blanket (P-UASB). Bioreactor systems for the removal of biodegradable organic matters provide satisfactory chemical oxygen demand (COD), biochemical oxygen demand (BOD) and total suspended solids (TSS) removal and possible reduction in pathogenic organisms as well as sufficient stabilization of accumulating bio-solids [5].

Packed-bed reactors have been widely used for the treatment of wastewater, such as brewery and dairy wastewaters. Anderson et al. [6] used a laboratory scale two anaerobic digestion systems treating dairy wastewater. The study showed that the overall removal efficiencies of COD and BOD were 90 and 95\%, respectively, at a hydraulic retention time (HRT) of 2 days. Also, Alvarado et al. [7] used anaerobic fluidized bed reactors to evaluate the organic removal from brewery wastewater. The reactor showed excellent COD removal with organic loading rate (OLR) up to $1 \mathrm{~kg} \mathrm{COD/day} \mathrm{at} \mathrm{HRT} \mathrm{of} 4$ days. Increased stability and performance in anaerobic UASB reactors can be achieved, if the microbial consortium is retained in the reactor. Two means of achieving this are to use dense bacterial granules or a microbial film attached to the inert carrier in packed-bed reactors. The packing medium in the packed-bed reactor serve as a filter preventing bacterial washout and also providing a large surface area for faster bio-film development and improved methanogenesis. Specific surface area, porosity, surface roughness, pore size and orientation of the packing material was found to play an important role in anaerobic reactor performance. Many carrier materials have been investigated regarding their suitability as supports for bio-film, including cheap, readily available material like sand, clay, glass, quartz and a number of plastics [8]. In nature, microorganisms inhabit the outer and inner surfaces of stones, gravel or sand. This bio-film formation on carrier materials improves the conversion rates by reducing its sensitivity toward concentration variations and inhibiting substances [9]. Tatara [10] showed that a packedbed reactor with carbon fiber textile (CFT) was applicable under very high OLRs and short HRTs even if it was compared with other processes using supporting materials such as anaerobic up-flow fixed-film reactor or fluidized bed reactor. The CFT provides the microorganisms with a place to grow and allows them to exist stably in the reactor. Also, Sanchez [11] used PVC plastic pipes and ceramic rushing rings and found that anaerobic fixed-bed reactor could work at high OLR without clogging.

In some cases, to reuse the treated wastewater in agriculture purposes, the use of anaerobic treatment alone may not be enough to comply with irrigation regulations. Accordingly, post treatment is required. One of these approaches is the use of multi-stage roughing fine filtration. Sand filters act as a complex staining process and microbiological action because the purification of wastewater takes place not only at the surface of the bed but also for some distance below. Vande [12] distinguishes three zones of purification in the sand bed; the surface coating (the schumtzdecke), the autotrophic zone, existing a few millimeters below the schumtzdecke and the heterotrophic zone which extends more $300 \mathrm{~mm}$ into the bed.

The aim of this study is to develop a combined treatment system which can provide a sustainable and appropriate low cost method producing a good quality effluent from municipal wastewater amenable for reuse. 


\section{MATERIAL AND METHODS}

\subsection{Description of the pilot plant treatment scheme}

The treatment scheme comprises an integrated combined treatment unit consisting of three successive compartments namely: up-flow anaerobic sludge blanket packed with lamella sheets (P-UASB) as the basic unit, inclined plate settler (IPS) and a multi-stage roughing fine filtration unit (MSRFF) as a post treatment for the anaerobically treated wastewater. Schematic and process flow diagrams of the treatment scheme are shown in Figs 1,2. The detailed engineering drawing of the MSRFF unit is shown in Fig. 3. The packing material in the UASB is lamella sheets with a specific surface area of $150 \mathrm{~m}^{2} / \mathrm{m}^{3}$.

\subsubsection{P-UASB}

The reactor of the P-UASB was designed and built for the anaerobic treatment step. It was designed based on the total flow of $10 \mathrm{~m}^{3} /$ day, and retention time ranged between 4 and $6 \mathrm{hrs} / \mathrm{day}$. The effective volume of the P-UASB is 2,200 1, with internal dimensions of $120 \times 120 \mathrm{~cm}$ and height of $240 \mathrm{~cm}$. The reactor was packed with Lamella corrugated sheets. The reactor was provided with the piping network for influent and effluent wastewater, wastewater sampling points, drainage pipe and

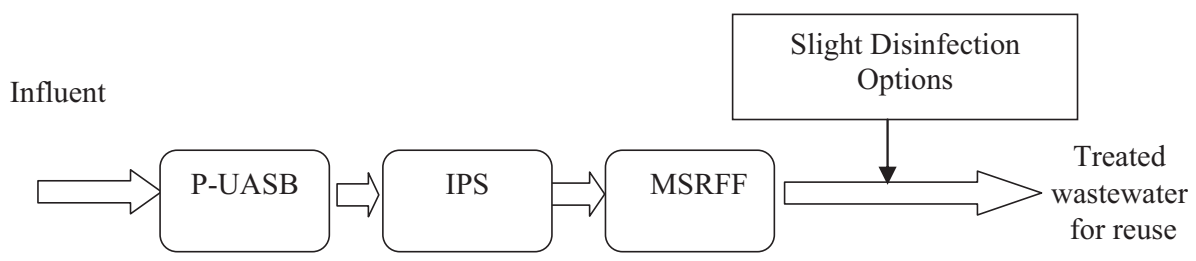

Figure 1: Schematic diagram of treatment scheme.

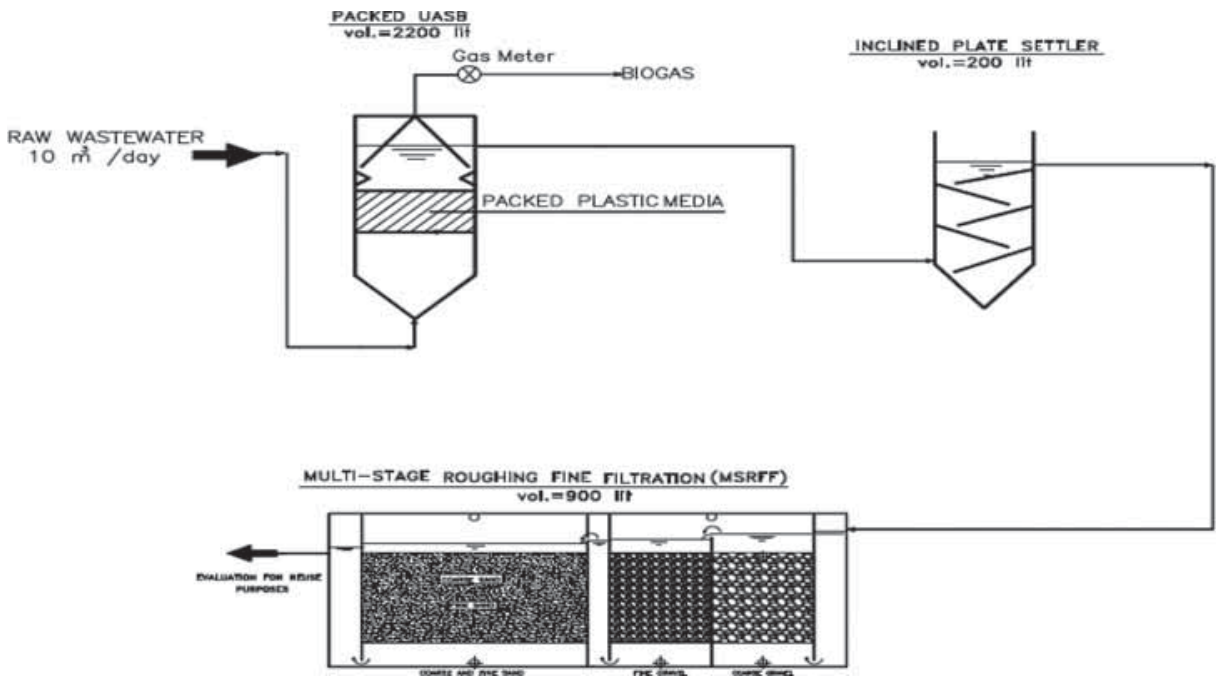

Figure 2: Process flow diagram of treatment scheme. 

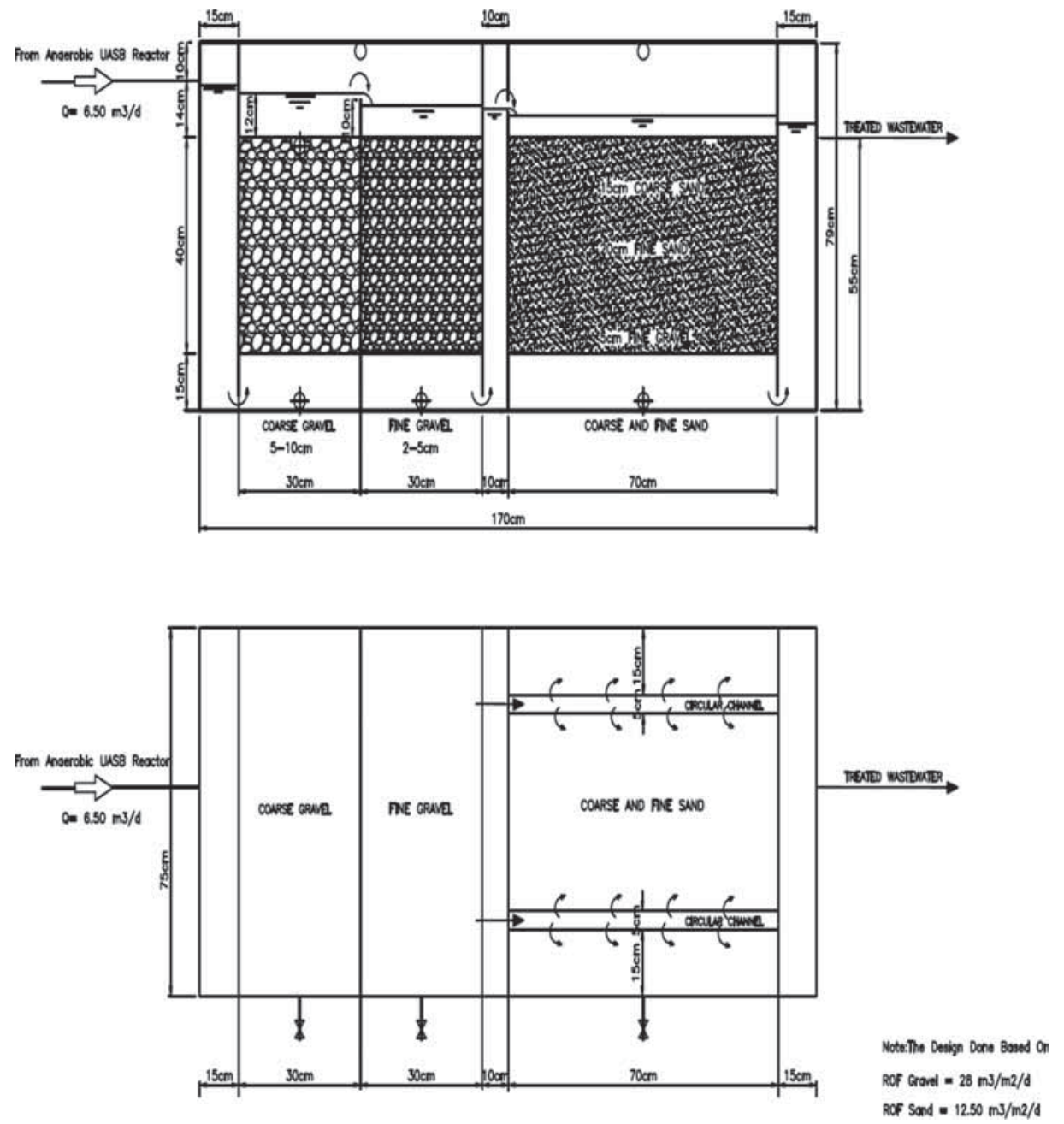

Figure 3: Schematic diagram of the MSRFF unit for post-treatment.

sludge sampling points at different distances along the reactor height. It was seeded with digested sludge collected from the digester of a secondary wastewater treatment plant.

\section{Design Criteria:}

Retention time $\quad=5 \mathrm{hrs}$.

Volume $\quad=2,200 \mathrm{~L}$

Sludge loading rate $(\mathrm{SLR})=0.1 \mathrm{~kg}$ COD $/ \mathrm{kg}$ VS. day

Volumetric OLR $\quad=1.5 \mathrm{~kg} \mathrm{COD} / \mathrm{m}^{3} /$ day

Up-flow velocity $\quad=0.5 \mathrm{~m} / \mathrm{h}$

\subsubsection{IPS}

An IPS was designed and built before MSRFF. The aim is to retain the suspended solids and biomass which may have escaped and washed-out from the P-UASB. The effective volume of the IPS is 2001 , 
with internal dimensions of $60 \times 60 \mathrm{~cm}$ and height of $150 \mathrm{~cm}$. The IPS unit was provided with inclined plates with inclination angle of $60^{\circ}$ in both directions. The clearance between the two sequential inclined plates is $10 \mathrm{~cm}$.

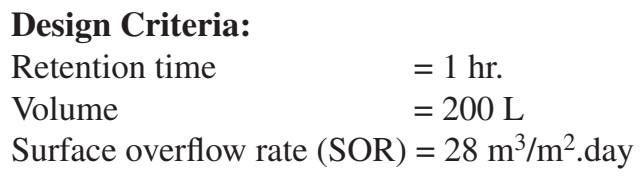

\subsubsection{Sand filtration unit}

- A MSRFF unit was designed to post-treat the anaerobic treated wastewater received from the P-UASB reactor. The total volume of the unit was $900 \mathrm{~L}$. The filtration unit was fabricated from PVC sheets with dimensions $30 \times 30 \mathrm{~cm}$ for roughing filter and $30 \times 50 \mathrm{~cm}$ for sand filter. The flow of wastewater received from IPS after the P-UASB was directed to the roughing filter in up-flow direction and to the sand filter in down-flow direction.

\section{Design Criteria:}

Rate of filtration $=150-200 \mathrm{~m}^{3} / \mathrm{m}^{2} /$ day for roughing filtration zone $=100-150 \mathrm{~m}^{3} / \mathrm{m}^{2} /$ day for fine filtration zone

- Filter Media: The roughing filtration zones were filled with three different sizes of gravel $(3,2$ and $1 \mathrm{~mm}$ in diameter). The sand filtration zone was filled with two different types of rough sand in the top layer followed by fine sand in the lower layer of the filter.

\subsection{Physico-chemical analysis}

The investigated physico-chemical analysis were: $\mathrm{pH}$, temperature, turbidity, total chemical oxygen demand (TCOD), soluble chemical oxygen demand (SCOD), biological oxygen demand (BOD5), TSS, volatile suspended solids (VSS) ; total kjeldahl nitrogen (TKN), ammonia $\left(\mathrm{NH}_{3}\right)$, total phosphorous (TP), oil and grease and all extractable matters by chloroform, hydrogen sulfide and volatile fatty acids (VFA). The gas produced was detected using portable ambient air analyzer (MIRAN SapphlRe, 205A series), while its flow was measured using a gas flow meter. All the analysis, unless otherwise specified, were carried out according to the American Public Health Association for the Examination of Water and Wastewater [13].

Calculation of COD fractions was carried out as follows:

COD sol $=$ COD filtered through membrane filter paper $(0.45 \mu \mathrm{m})$

COD coll $=\mathrm{COD}$ of the filtrate from $4.4 \mu \mathrm{m}$ filter paper $-\mathrm{COD}$ of the filtrate from membrane filter paper $(0.45 \mu \mathrm{m})$

COD sett $=$ Total COD - COD of the filtrate from $4.4 \mu \mathrm{m}$ filter paper

\subsubsection{Biological and parasitological examination}

The bacteriological examinations for Fecal Coliform (FC) and Salmonella group were carried out $[14,15]$. The parasitological examinations were investigated for total helminthes (nematodes, cestodes and trematodes) [13].

\section{START UP OPERATING CONDITIONS}

The pilot plant was operated continuously for almost 10 months at a hydraulic loading rate of $10 \mathrm{~m}^{3} /$ day (in the P-UASB reactor) with an average OLR of $3.27 \mathrm{~kg} \mathrm{COD} / \mathrm{m} 3 /$ day. The pilot plant was operated at ambient temperature ranging from $17^{\circ} \mathrm{C}$ to $35^{\circ} \mathrm{C}$. The system was fed with municipal 
wastewater, after coarse screen, to prevent clogging and damage caused by rough suspended solids of influent wastewater. During the start-up period, the flow rate was gradually increased from $2.0 \mathrm{~m}^{3} /$ day up to $10 \mathrm{~m}^{3} /$ day until the P-UASB reached the steady-state conditions.

\subsection{Acclimatization and sludge inoculation}

The acclimatization period of the treatment system took about 4 months from the first inoculation to the P-UASB reactor. It was seeded with primary digested sludge obtained from a secondary wastewater treatment plant. The sludge is kept in anaerobic condition before feeding to the P-UASB. The seeded sludge has a concentration of $63.4 \mathrm{~g} / 1$ for TSS and $27.3 \mathrm{~g} / 1$ for VSS. The volume of the sludge represents almost $40 \%$ of the total volume of the P-UASB reactor. During the steady-state operation phase, the excess sludge was discharged every 2 months. Before sludge withdrawal, several sludge samples were collected from the different points along the reactor height at 10, 28, 41, 54 and $69 \mathrm{~cm}$ from the reactor bottom. These samples were analyzed for total solids (TS) and volatile solids (VS). Accordingly, the composite sludge concentration inside the reactor was calculated and compared to that of the starting initial value of the seeded sludge as a potential to determine the excess sludge concentration. In each wasting case, the volume of the excess sludge was observed. Furthermore, the performance of the integrated anaerobic treatment system was monitored by intermittent measurements of COD and TSS until it reached the steady state.

\section{RESULTS}

\subsection{Steady-state conditions and adaptation}

To reach the steady-state conditions, the system was operated at $2.88 \mathrm{~m}^{3} /$ day then gradually increased to $4.33 \mathrm{~m}^{3} /$ day and then to $6.0 \mathrm{~m}^{3} /$ day until it reached $10 \mathrm{~m}^{3} /$ day. The system reached the steady state after almost 4 months as indicated by constant measurements of total COD and TSS (Figs 4, 5).

\subsection{Effect of HRT (6 h)}

The P-UASB was operated at two retention times, namely $6 \mathrm{~h}$ HRT and $4 \mathrm{~h}$ HRT. Figures $6-8$ show the efficiency of the treatment system at HRT of $6 \mathrm{~h}$. The results revealed that the system achieved sustainable and satisfactory reductions in the total $\mathrm{COD}, \mathrm{BOD}_{5}$ and TSS. Their corresponding removal values reached, 76.7, 77 and $86.2 \%$, respectively, with corresponding residual values of 85 , 54 and $28 \mathrm{mg} / \mathrm{l}$. These results indicated that the use of the packing material (lamella sheets) enhanced the removal efficiency of the organic materials [8]. These results are in agreement with Refs. [5]. and [8] although they operated the UASB at higher hydraulic loading rate.

\subsection{Effect of HRT (4 h)}

Figures 9-11 show that decreasing the retention time from 6 to $4 \mathrm{~h}$ in the P-UASB did not noticeably affect the performance of the removal rates of TCOD, BOD5 and TSS. The treated effluent after IPS achieved removal rates of $75,70.6$ and $91.3 \%$, respectively.

Pendent on the results obtained, it can be concluded that the pilot plant can be operated efficiently at a short HRT of $4 \mathrm{~h}$ which will greatly decrease the construction cost of the treatment system. 


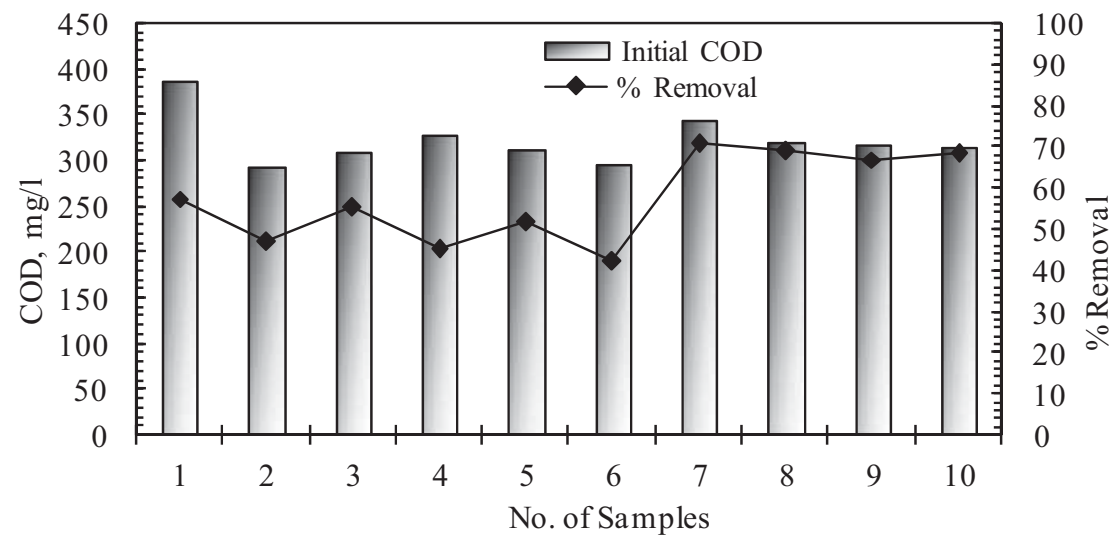

Figure 4: Percentage removal of COD from PUASB-IPS during the steady-state condition.

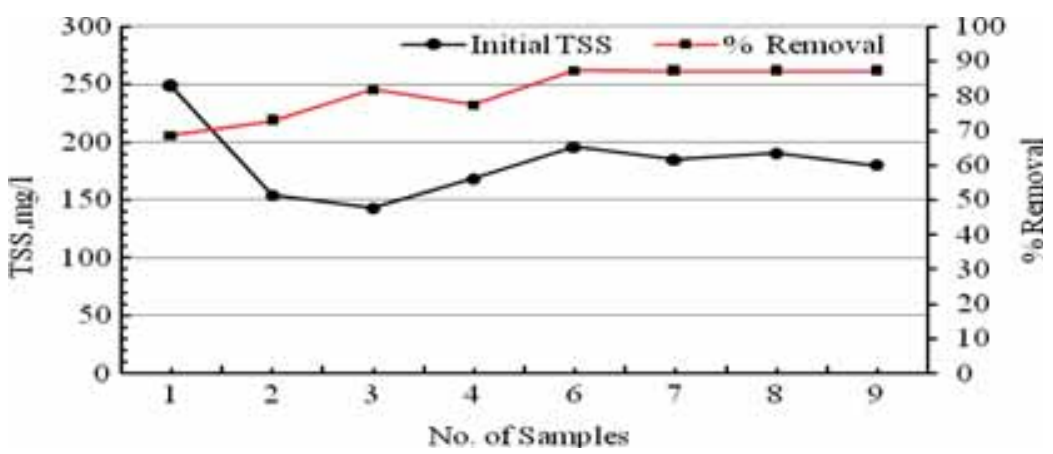

Figure 5: Percentage removal of TSS from PUASB-IPS during the steady-state conditions.

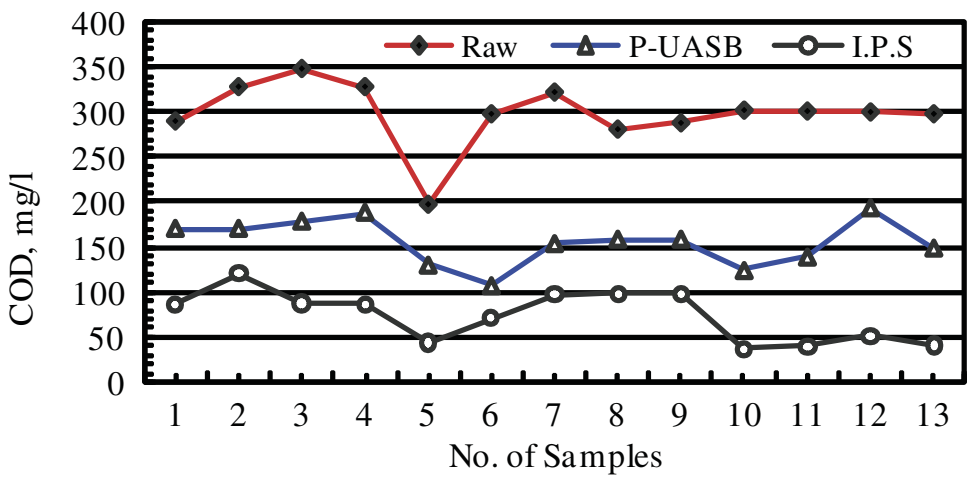

Figure 6: Percentage removal of COD from PUASB-IPS at $6 \mathrm{~h}$ HRT. 


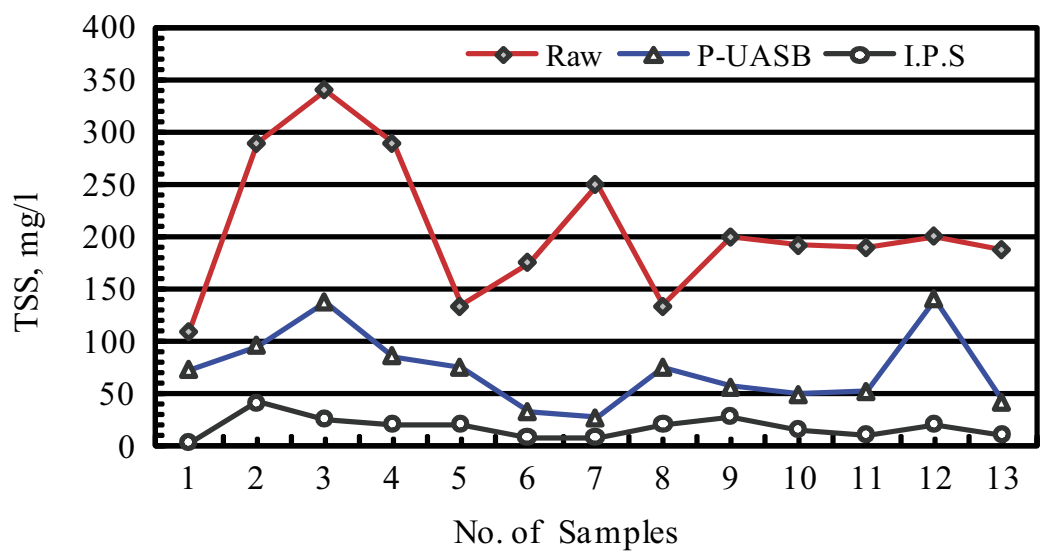

Figure 7: Percentage removal of TSS from PUASB-IPS at $6 \mathrm{~h}$ HRT.

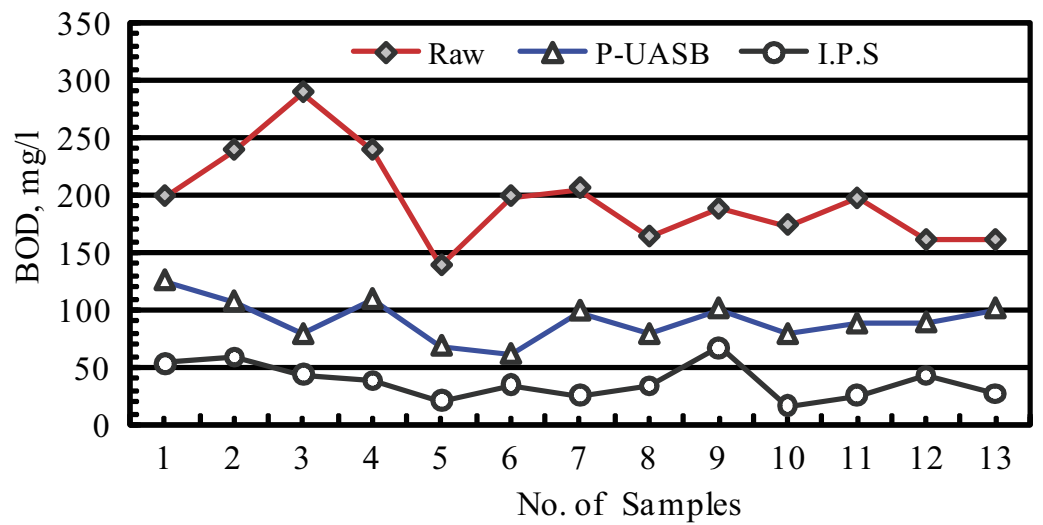

Figure 8: Percentage removal of BOD from PUASB-IPS at $6 \mathrm{~h}$ HRT.

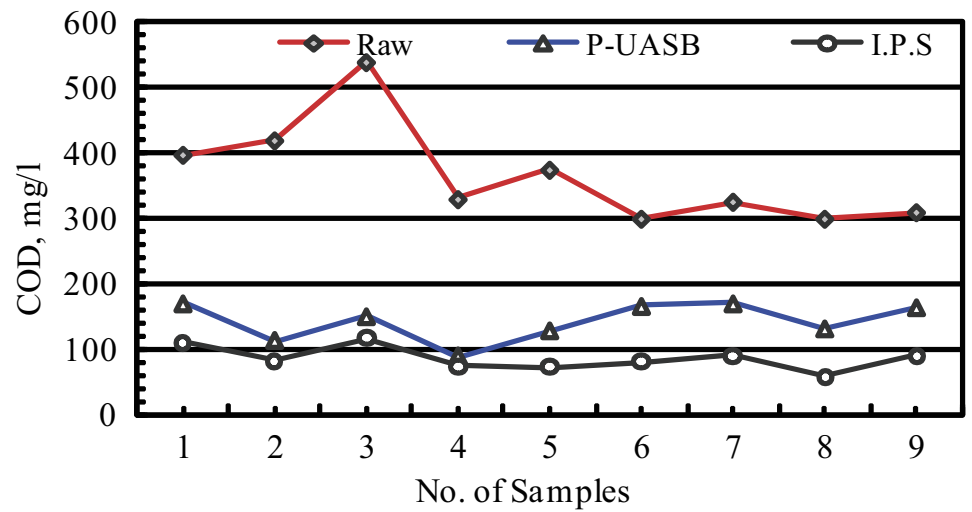

Figure 9: Percentage removal of COD from PUASB-IPS at 4 h HRT. 


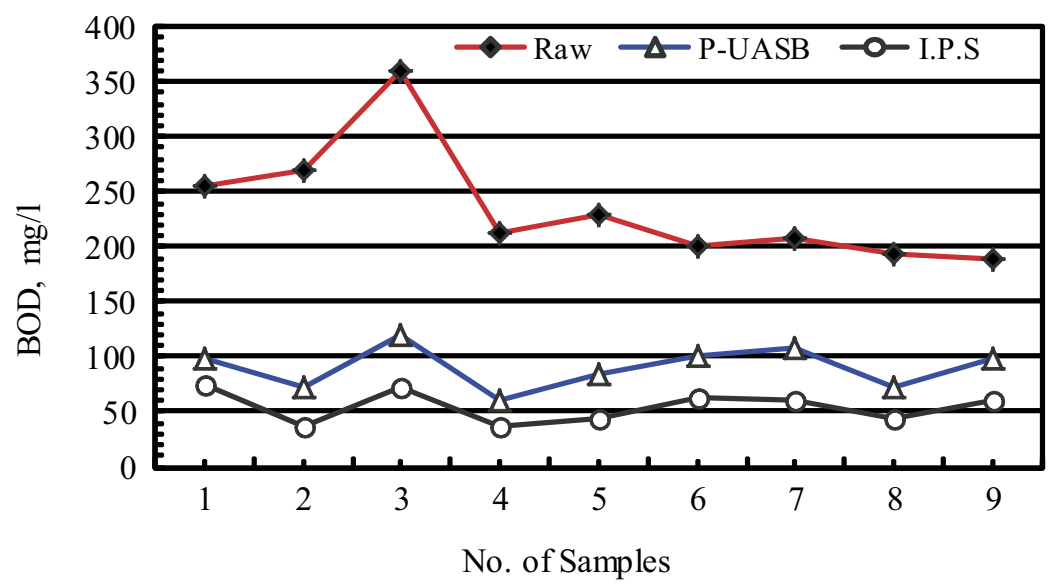

Figure 10: Percentage removal of BOD from PUASB-IPS at $4 \mathrm{~h}$ HRT.

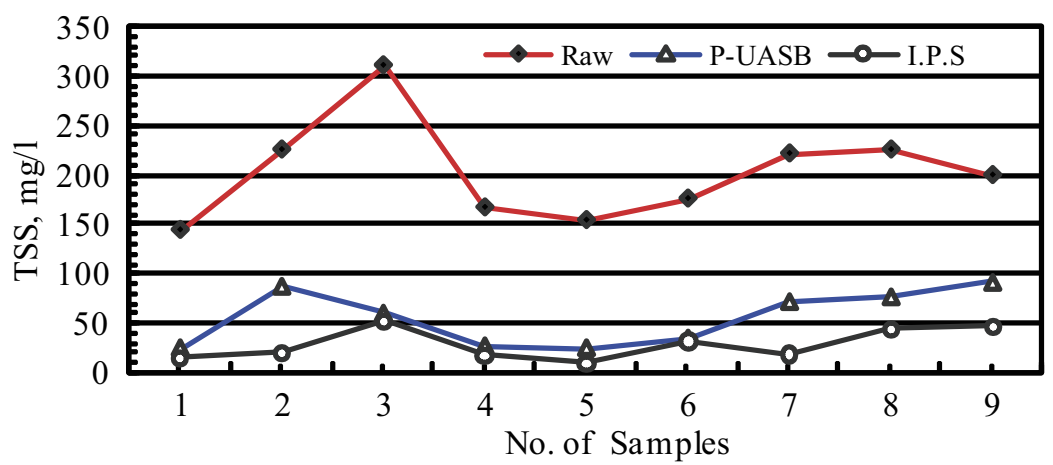

Figure 11: Percentage removal of TSS from PUASB-IPS at $4 \mathrm{~h}$ HRT.

\subsection{Biogas production}

The quantity and quality of biogas produced were measured frequently. The methane content ranged between 72 and $77 \%$ of the total biogas. Also, the biogas included some other gases such as $\mathrm{N}_{2}, \mathrm{NH}_{3}$, $\mathrm{CO}_{2}, \mathrm{CO}$ and $\mathrm{N}_{2} \mathrm{O}$. The specific methane gas production was determined according to the removed $\mathrm{COD}$ and influent $\mathrm{COD}$ as well as the influent wastewater flow. The removed COD-specific $\mathrm{CH}_{4}$-gas production ranged between 180 and $220 \mathrm{~L} \mathrm{CH}_{4} / \mathrm{kg}$ COD removed with an average value $200 \mathrm{~L} \mathrm{CH}_{4} / \mathrm{kg}$ COD removed. The influent COD-specific $\mathrm{CH}_{4}$-gas production ranged between 80 and $160 \mathrm{~L} / \mathrm{kg} \mathrm{COD}$ in with an average value of $120 \mathrm{~L} / \mathrm{kg}$ COD along the study period. In comparison with other research works, it is proved that the obtained values are considered in a normal range of methane production for anaerobic treatment of municipal wastewater $[16,17]$.

\subsection{Pathogens removal}

Pathogenic microorganisms in wastewater can be transmitted to healthy individuals and cause diseases if improper regulation and control methods in wastewater irrigation are practiced [18]. 
Obviously, the degree of wastewater treatment particularly as it relates to the effective removal and inactivation of pathogenic microorganisms will have critical effect in controlling any possible health risks associated with wastewater irrigation. FC bacteria are regarded as the most useful indicator for microbiological purifications achieved by wastewater treatment and disinfection [19]. Anaerobic digestion process is generally less effective in microbiological removal. The removal rates are between 59.7 and $93 \%$ [20].

In our study, treatment of raw wastewater using P-UASB followed by IPS removed almost three $\operatorname{logs}$ of FC/100 ml, with a $99.92 \%$ removal reached (Table 1).

\subsection{Post treatment}

In this study a MSRFF unit was used as a post-treatment for the anaerobically treated effluent to improve the quality of wastewater from P-UASB to meet the National Code for Wastewater Reuse in Restricted Irrigation (501/2005) [21]. The average residual concentrations of COD, BOD, TSS, TKN and TP were $60 \mathrm{mg} / \mathrm{l}$ and 34.6mg/l, $10.9 \mathrm{mg} / \mathrm{l}, 1.4 \mathrm{mgN} / \mathrm{l}$ and $18.8 \mathrm{mg} / \mathrm{l}$, respectively as shown in Figure 12.

Table 1: FC removal after anaerobically treated process.

\begin{tabular}{lcc}
\hline & \multicolumn{2}{c}{ MPN - index/100 ml } \\
\cline { 2 - 3 } Samples & Raw wastewater & IPS \\
\hline 1 & $1.5 \times 10^{7}$ & $1.2 \times 10^{4}$ \\
2 & $1.5 \times 10^{6}$ & $2.1 \times 10^{3}$ \\
3 & $1.4 \times 10^{7}$ & $3.6 \times 10^{3}$ \\
4 & $7 \times 10^{6}$ & $1.1 \times 10^{3}$ \\
5 & $9 \times 10^{5}$ & $6.2 \times 10^{3}$ \\
6 & $7 \times 10^{6}$ & $3.4 \times 10^{3}$ \\
7 & $1.5 \times 10^{7}$ & $2.1 \times 10^{4}$ \\
8 & $2 \times 10^{7}$ & $1.1 \times 10^{4}$ \\
\hline
\end{tabular}

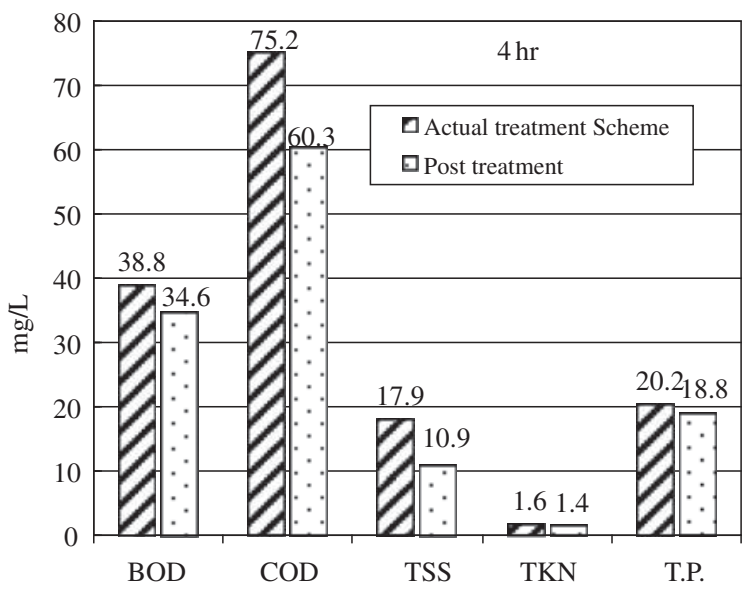

Figure 12: Residual values of BOD, COD, TSS, TKN and TP after anaerobic P-UASB followed by MSRFF. 
Table 2: Efficiency of overall treatment scheme for FC removal.

\begin{tabular}{lcc}
\hline & \multicolumn{2}{c}{ FC - MPN - index/100 ml } \\
\cline { 2 - 3 } Samples & Influent & Effluent \\
\hline 1 & $1.5 \times 10^{7}$ & $1.5 \times 10^{3}$ \\
2 & $1.5 \times 10^{6}$ & $9 \times 10^{2}$ \\
3 & $1.4 \times 10^{7}$ & $7.0 \times 10^{2}$ \\
4 & $7.0 \times 10^{6}$ & $4.8 \times 10^{2}$ \\
5 & $9.0 \times 10^{5}$ & $9.3 \times 10^{2}$ \\
6 & $7.0 \times 10^{6}$ & $2.8 \times 10^{2}$ \\
7 & $1.5 \times 10^{7}$ & $1.5 \times 10^{3}$ \\
8 & $2.0 \times 10^{7}$ & $2.8 \times 10^{2}$ \\
Min & $9.0 \times 10^{5}$ & $2.8 \times 10^{2}$ \\
Max & $2.0 \times 10^{7}$ & $1.5 \times 10^{3}$ \\
Average & $1 \times 10^{7}$ & $8.2 \times 10^{2}$ \\
\hline
\end{tabular}

Table 3: Efficiency of overall treatment scheme for Salmonellae removal.

\begin{tabular}{lcc}
\hline \multicolumn{3}{c}{ Salmonella group - MPN-index/100 ml } \\
\hline Samples & Influent & Effluent \\
\hline 1 & $1.1 \times 10^{5}$ & $1.1 \times 10^{2}$ \\
2 & $3.1 \times 10^{4}$ & $1.0 \times 10^{2}$ \\
3 & $1.3 \times 10^{5}$ & $1.0 \times 10^{2}$ \\
4 & $2.3 \times 10^{4}$ & $9.0 \times 10$ \\
5 & $3.6 \times 10^{3}$ & $1.0 \times 10^{2}$ \\
6 & $2.7 \times 10^{4}$ & $2.7 \times 10^{4}$ \\
7 & $1.3 \times 10^{5}$ & $9.0 \times 10$ \\
8 & $1.6 \times 10^{5}$ & $1.4 \times 10^{2}$ \\
Min. & $3.6 \times 10^{3}$ & $9.0 \times 10$ \\
\hline
\end{tabular}

In addition, the overall efficiency of the treatment scheme for FC and Salmonella removals are shown in Tables 2, 3. The results indicated that the use of MSRFF as a post-treatment removed five $\operatorname{logs}$ for FC and three logs for Salmonella as an average values. Salmonellae group in wastewater ranged between 103 and $105 \mathrm{MPN}$-index/100 ml. On the other hand, Salmonellae group after sand bed ranged between 10 and 102. The average removal rate was $103 \mathrm{MPN}$-index/100ml.

However, total helminthes (nematodes, cestode and trematodes) could not be removed completely due to the short HRT $(4 \mathrm{~h})$ and the high up-flow velocity in the P-UASB. The mean values of nematodes, cestode and trematodes (Table 4 ) indicated that the total helminthes reached 0.3 ova/l. Huajun et al. [22] reported that anaerobic process had certain effect on the removal of pathogenic species, such as FC and Ascaris eggs, but it is necessary to take further appropriate post-disinfection process to guarantee the effluent safety. In our study, FC and total helminthes ova comply with the National 


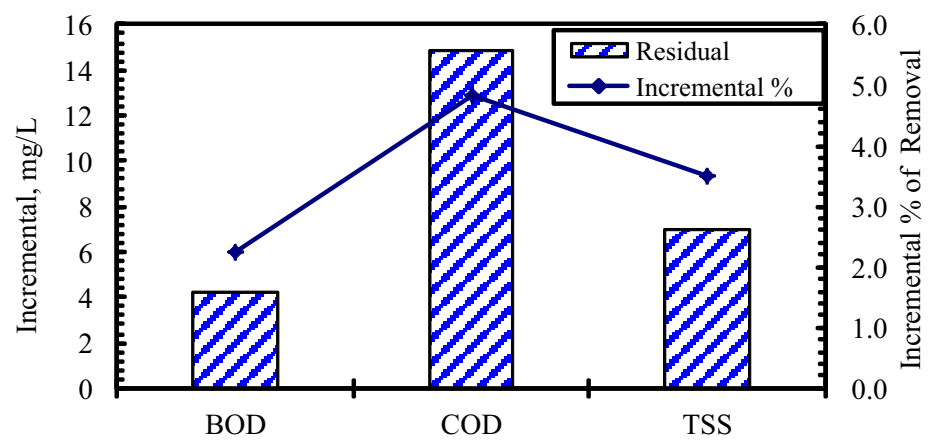

Figure 13: Incremental percentage of BOD, COD and TSS removal and its concentration for posttreatment MSRFF.

Table 4: Efficiency of treatment scheme for helminthes removal.

\begin{tabular}{lll}
\hline & \multicolumn{2}{c}{ Ova/l } \\
\cline { 2 - 3 } Helminthes & \multicolumn{1}{c}{ Influent } & \multicolumn{1}{c}{ Treated effluent } \\
\hline Nematodes & 2.1 Tricho 1.6 Asca 0.4 Trichu & 0.6 Asca 0.1 Trichu \\
Cestodes & 1 Hymen 0.3 Taen & 0.3 Taen \\
Trematodes & N.D & N.D \\
\hline
\end{tabular}

Asca $=$ Ascaris, Hymen $=$ Hymenolepis, Taen $=$ Taenia, Tricho $=$ Trichostrongylus, Trichu $=$ Trichuris, N.D: Not Detected.

Code for wastewater reuse in restricted irrigation (501/2005 code). However, for more safe effluent, slight disinfection is recommended.

\section{CONCLUSION}

Based on the results obtained, the followings were concluded:

1. The anaerobic treatment of low strength wastewater using P-UASB followed by IPS produced a good quality effluent at a short retention time $(4 \mathrm{~h})$. The average removal rates of COD, BOD and TSS reached $75,70.3$ and $91 \%$, respectively.

2. The use of MSRFF as a post-treatment improved the quality of treated effluent both chemically and biologically. Average residual values of COD, BOD and TSS were 60, 34 and $10.9 \mathrm{mg} / \mathrm{l}$, respectively. Almost complete removal of bacterial indicators of pollutions were achieved. However, slight disinfection was recommended to insure the safe reuse of wastewater for irrigation purposes.

3. Results indicated that the proposed treatment scheme proved to be a very promising approach for municipal wastewater reuse in restricted irrigation.

4. The use of treated wastewater will eventually save at least $0.7 \mathrm{BCM} / \mathrm{year}$ of freshwater used for irrigation. 


\section{ACKNOWLEGMENT}

The authors would like to thank the science and technology development fund, The Egyptian Academy of Scientific Research and Technology for the research grant (STDF/1088).

\section{REFERENCES}

[1] WHO, Joint Monitoring Program for Water Supply and Sanitation. Coverage Estimates Improved Drinking Water, World Health Organization, UNICEF, 2011.

[2] Abdel Wahaab, R. \& Omar, M., Wastewater reuse in Egypt: opportunities and challenge, Egypt country report for reuse, 2012.

[3] El-Gohary, F.A. \& Nasr, F.A., Cost effective pre-treatment of wastewater. Water Science Technology, 39(5), pp. 97-103, 1999. doi: http://dx.doi.org/10.1016/S0273-1223(99)00113-4

[4] Looker, N., Municipal wastewater management in Latin America and the Caribbean, R.J. Burnside international limited, published for roundtable on municipal water for the Canadian environment industry association, 1998.

[5] Lettinga, G., Anaerobic digestion and wastewater treatment systems. Anton leeuw, 67, pp. 3-28, 1995.

[6] Anderson, G.K., Kasapgil, B. \& Ince, O., Comparison of porous and non-porous media in upflow anaerobic filters when treating diary wastewater. Water Science Technology, 32, pp. 2707-2713, 1998.

[7] Alvarado-Lassman, A., Rustrian, E., Garcia-Alvarado, M.A., Rodriguez Jimenez, G.C. \& Houbron, E., Brewery wastewater treatment using anaerobic inverse fluidized bed reactors. Biosource technology, 99, pp. 3009-3015, 2008.

[8] Picanco, A.P., Vallero, M.V.G., Gianotti, E.P., Zaiat, M. \& Blundi C.E., Influence of porosity and composition of supports on the methanogenic biofilm characteristics developed in a fixed bed anaerobic reactor. Water Science Technology, 44, pp. 197-204, 2001.

[9] Dullemont, Y.J., Schiven, J.F. \& Hunjen,W.A., Removal of microorganisms by slow sand filtration, Recent progress in slow sand and alternative biofiltration process, publishing: IWA, 2006.

[10] Tatara, M., Yamazawa, A., Ueno, Y., Fukui, H., Goto, M. \& Sode, K., High-rate thermophilic methane fermentation on short-chain fatty acids in a down-flow anaerobic packed-bed reactor. Bioprocess Biosystem Engineering, 27, pp. 105-115, 2004. doi: http://dx.doi.org/10.1007/ s00449-004-0387-8

[11] Sanchez, R., Montalvo, S., Travieso, L. \& Radriguez, X., Anaerobic digestion of sewage sludge in an anaerobic fixed bed digester. Biomass Bioenergy, 9(6), pp. 493-5, 1995. doi: http://dx.doi.org/10.1016/0961-9534(95)00038-0

[12] Van de Vloed, A., Comparison between slow sand and rapid filters, Proc.3rd congress of the IWSA, London, 1955.

[13] APHA, Standard Methods for the Examination of Water and Wastewater. 22th edn, American Public Health Association: Washington, DC, USA, 2005.

[14] Engelbrecht, R.S. \& Lalchandani, A., New microbial indicators of disinfection efficiency, U.S., EPA. 600/1-77-052, 1977.

[15] Al-Herrawy, A.Z., Incidence of cryptosporidium oocysts in domestic wastewater using light microscopy and PCR. Egypt Journal of Microbiology, 41, pp. 89-99, 2006.

[16] Ghaniyari-Benis, S., Borja, R., Ali Monemian, S. \& Goodarzi, V., Anaerobic treatment of synthetic medium-strength wastewater using a multistage biofilm reactor. Biosource technology, 100, pp. 1740-1745, 2009. 
[17] Kobayashi, H.A., Stenstrom, M.K. \& Mah, R.A., Treatment of low strength wastewater using the anaerobic filter. Water Research, 17(18), pp. 903-909, 1982.

[18] Mara \& Horan, Handbook of water and wastewater microbiology, 2003.

[19] Shuval, H.I., Lampert, \& B. Fattal., Development of a risk assessment approach for evaluating wastewater reuse slandered for agriculture, Water Science and Technology, 35, pp. 15-20, 1997. doi: http://dx.doi.org/10.1016/S0273-1223(97)00228-X

[20] Who, Health guidelines for the use of wastewater in agriculture and aquaculture, Technical Report Series No.778, World Health Organization: Geneva, 1989.

[21] Egyptian Code ECP 501-2005, Egyptian standards for reuse of the treated sewage in agriculture, 2005.

[22] Huajun Feng, A., Lifang Hu, A., Qaisar Mahmood, B., Caidi Qiu, A., Chengran Fang, C. \& Dongsheng, Shen., Anaerobic domestic wastewater treatment with bamboo carrier anaerobic baffled reactor. International Biodeterioration \& Biodegradation, 62, pp. 232-238, 2008. doi: http://dx.doi.org/10.1016/j.ibiod.2008.01.009 